IRA-International Journal of Education \& Multidisciplinary Studies

ISSN 2455-2526; Vol.06, Issue 02 (2017)

Pg. no. $156-162$

Institute of Research Advances

http://research-advances.org/index.php/IJEMS

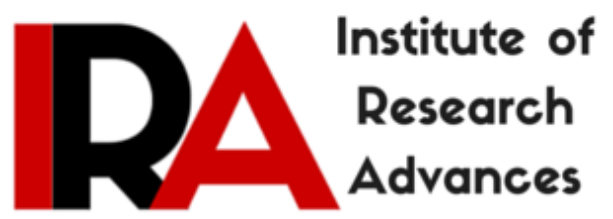

\title{
Manipuri Ramkatha through Wari Leeba: A Dialogue between Text and Oral Renditions
}

\begin{abstract}
Ahanthem Homen Singh
Research Scholar, Department of Modern Indian Languages and Literary Studies, University of Delhi, Delhi, India.
\end{abstract}

Type of Review: Peer Reviewed.

DOI: http://dx.doi.org/10.21013/jems.v6.n2.p2

\section{How to cite this paper:}

Singh, A. (2017). Manipuri Ramkatha through Wari Leeba: A Dialogue between Text and Oral Renditions. IRA International Journal of Education and Multidisciplinary Studies (ISSN 2455-2526), 6(2), 156-162. doi:http://dx.doi.org/10.21013/jems.v6.n2.p2

(C) Institute of Research Advances

\section{(cc) EY-NC}

This work is licensed under a Creative Commons Attribution-Non Commercial 4.0 International License subject to proper citation to the publication source of the work.

Disclaimer: The scholarly papers as reviewed and published by the Institute of Research Advances (IRA) are the views and opinions of their respective authors and are not the views or opinions of the IRA. The IRA disclaims of any harm or loss caused due to the published content to any party. 


\begin{abstract}
The paper seeks to highlight the dynamism of Indian Literary traditions which blurs the strict compartmentalization of written and oral traditions. Taking an instance from the Manipuri Ramayana in written text and its oral rendition through the narrative art of Wari Leeba, the paper tries to delineate the negotiation and interaction between the various forms of expressions in Indian literary scenario. From a detailed study of how the Manipuri Ramkatha tradition develops in Manipur to the way how Wari Leeba as a narrative art evolves and associates itself with recitation of Ramkatha in Manipur, the paper gives an insight into the various aspects of their interaction and corresponding cultural ethos. Social and religious context associated with the evolution and development of Ramkatha and Wari Leeba has been dealt with in this paper.
\end{abstract}

Keywords: Ramkatha, Manipuri Ramayana, Wari Leeba, written and oral traditions, performance, narrative art, scripto-centric, phono-centric.

\title{
Introduction
}

Ramkatha or the story of Rama has been consistently making its presence felt in this subcontinent from a very early time. Apart from the Ramayana of Valmiki which is considered as the ur-text and other popular Rama stories in written forms such as Iramavataram or Kamba Ramayana of Kamban (Tamil), Krittivasi Ramayana of Krittivas (Bengali), Ramcharitmanas of Tulsidas, Madhav Kandali's Ramayana (Assamese), to name a few, we come upon scores of Ramkatha or 'story of Rama' in different parts of India and in various regional languages. It is generally observed that translation, adaptation, rerendering, re-telling of the Ramayana are found in almost all the regional literatures of India. And it is here one can really witness the parochial aesthetics and cultural markers, not only in terms of language, lexicon, imageries etc. but the local legends, myths and folk narratives being infused into it so appropriately that the resultant product becomes a unique 'Ramkatha'. These indeed are some of the unique characteristics of this great epic of India. Not only through text or scripto-centric format, but through oral and performance traditions also, the story of Rama has traversed both spatially and temporally in India and has become a tradition itself. The extent of this tradition is observed not only in performance, narration, sculpture, painting, songs and festivals. But also related to sacred geographies and places of pilgrimage and shared ethos of different communities. It is thus favourably considered as the connecting link between the various cultures present in this sub-continent by those who vouched for a common cultural heritage of India.

\section{The Manipuri Ramayana in Written Tradition}

Likewise the tradition of Ramkatha has its share in the cultural manifestations of Manipur, which lies on the north-eastern part of India. The Ramkatha tradition has been continuing in the literary and cultural mode of the Manipuris since the early part of $18^{\text {th }}$ century AD in the wake of introduction of Ramandi Hinduism by King Garibniwaz (1709-1748). Ramkatha made its way in Manipur along with the waves of Vaishnavism in the $18^{\text {th }}$ century A.D. and has made its impact on several aspects of the Manipuri society. In the context of Manipur, notwithstanding its religious affiliation and proselytizing ventures, the story of Rama constitutes an important aspect of the cultural heritage of the people of Manipur. Starting with the installation of images of Rama, Lakshmana, Bharata, Satrughana and Sita at Ramji Prabhu temple and that of Hanuman at Mahabali temple by Maharaja Garibniwaz (1709-1748 AD) in order to popularize the worship of Rama, the tradition of Ramkatha continued till date. ${ }^{i}$ In the literary scenario, we came upon translations of Krittivas's Ramayana from Bengali to Manipuri done by scholars under the patronage of the rulers of Manipur. It is mentioned that under the instruction of Maharaj Garibniwaz, Kshema Singh Moiramba and other five persons translated the seven Kanda of Krittivas's Ramayana into Manipuri. ${ }^{\text {ii }}$ Another renowned scholar named Pundit Angom Gopi along with Murari, also a court poet also translated the Birbahu Tuba (The Fall of Birbahu) in 1713 AD under the instruction of the aforementioned king. Continuing the literary trend, King Labayanchandra (1798-1800 AD) directed 
Shridam Keisham Chana to recompose the earlier translations of Ramayana as some of them were lost due to Burmese occupation of Manipur in $1758 \mathrm{AD}$. ${ }^{\text {iii }}$ There are also a number of texts were in Manipuri which were actually adaptations and re-renderings of Ramayana. Mentioned may be made of Ram Nonggaba written by Konthoujam Labanga under the auspices of Maharaja Chingthangkhomba popularly known as Maharaja Bhagyachandra (1764-1793 AD) who wanted him to compose the heavenward journey of Rama after the Uttara Kanda episode. A look into these texts offered us the nature of regional appropriation and adaptation of the Ramayana by the Manipuris. However much more interesting is the way in which Ramkatha made its presence felt and communicated its ideals and essence to the people through various forms of expression. Here we came upon cases of various narrative and performing traditions such as Lairik Thiba Haiba, Wari Leeba, Khongjom Parva, Sumang Leela et al through which the epic is circulated and disseminated in Manipur.

In this paper I would like to focus on a narrative tradition of Manipur which is one of the popular channels of dissemination of the story of Rama or Ramkatha. Wari Leeba (wari-story, leeba- to tell) is a narrative art form of Manipur. There are no extant documentations of the genesis of this art form. In a sense, this narrative art which has been continuing through oral tradition has taken its references orally. Thus, the genesis and evolution of this art form still open up provision for debates as concrete evidences are lacking in these matters. ${ }^{\text {iv }}$ It is believed that this narrative art form was evolved during the reign of King Khagemba who ruled over Manipur from 1598 to 1652 AD. However, information regarding the exact style of this narrative art and the stories which were narrated through this art is still obscured. It is only during the reign of Maharaja Bhagyachandra that Jeoram Sharma from Tekhao (Assam as called by the Manipuri then) in the year 1775 introduced the art of narrating story from Bhagava Gita, the epics and the Hindu Puranas. ${ }^{\mathrm{v}}$ From then onwards, Wari Leeba became a popular medium through which texts associated with Vaishnavite faith are dispersed in Manipur. Though religious affiliation is very much evident in this form and hard to segregate from the propagandist nature of Vaishnavism, one can also attempt a study of Wari Leeba as presenting the growth and sustenance of an art form. Notwithstanding its religious connotation, Wari Leeba has earned itself a place in the Manipuri cultural arena as an art form which carries a tradition of its own. But coming to the main crux of this paper; Wari Leeba as an important medium for transmission and popularization of Ramkatha in Manipur, let us have a glance at the characteristics of this art form.

\section{Wari Leeba, a narrative art of Manipur and Manipuri Ramkatha}

Wari Leeba is a narrative art articulating stories and episodes from the Ramayana, Mahabharata and Hindu Puranas. Here, a single narrator recites episodes from these texts with gestures and well modulated voice to evoke suitable rasa (sentiments) among the audiences. The narrator narrates in colloquial Meiteilon (or Manipuri language) and uses relevant metaphors and imageries from the local language to narrate the stories. A little sprinkling of Sanskrit and Bengali slokas (metrical forms) and words during the course of narration is observed as of necessity (for the narrators basically learned the stories as taught to them by their predecessors from the Ramayana written either in Bengali or Sanskrit) and also to show their comfort level with these languages apart from attracting the audiences. This mingling and fusing of lexicons and metaphors and idioms also give us the impression of two cultures in negotiation and conventions of the Vaishnavite ethos is distinctively visible. Elangbam Nilakanta Singh, a renowned Manipuri scholar wrote:

'Wari Leeba constitutes an extremely popular medium of mass communication. The Wari Leebas narrated for days and nights the episodes of the Ramayana with gusto and creative imaginations, making people laugh, weep and cry at the various stages of the narrations. The character of Ramayana under the impact of Krittivas, Adhyatma and Yoga-Vashistha Ramayana and coloured by the regional touch of culture became unforgettable creations in the context of Vaishnava Bhakti." vi 
As a technique of articulation, the narrators narrate in direct and indirect forms of speech and verbally dramatize the story through their performing skills. He is Rama, Ravana, Hanuman, Sita, Shiva (as narrating to his wife Parvati) donning the exponents of the entire characters associated with the Ramayana. The narrator sits on a phak (reed mat) with one bolster as his props. A lairik phan (small table for keeping the holy book), paana-kwa (betel leaf and nut), heiruk-heirang (offerings of fruit and flowers) and a candle are kept in front of the narrator. Usually the performances take place within the temple arenas. Mandop as commonly called in Manipur is an extension of the temple where religious conglomeration, rituals, dance, music and festivals associated with Hindu faith are performed. Though this enclosed and roofed structure is also used for community feast, meeting and discussion as well as for marriages and other religious and social events, but there is an unsaid code which allows for those connected with Hindu religious followers. The place of performance of this narrative art is also important while locating the specific purpose of the narration of the story of Rama. As mentioned before the tradition of Ramayana came along with the wave of Vaishnavism. Thus the religiosity associated with this narrative art form is very much evident from this performance space. It is usually performed during Kalen (Vyaistha; May-June) and Mera (Kartikkaya; October-November) for the whole length of the month at different parts of the state. People, basically the followers of Vaishnavism thronged the Mandop where these narrations take place. The sanctity of the narrative art is best reflected in the way in which there is a special ashran or seat reserved for Hanuman, the Bhakta of Rama, next to the narrator's seat, near the stool where the text of Ramayana is kept. Wari leeba is also performed on marriages, swasti puja (performed on the $6^{\text {th }}$ day after the birth of a child), nahutpa (ear-piercing ceremony) and death anniversaries. It is also believed that listening to episodes from Ramayana can make an infertile woman conceived. ${ }^{\text {vii }}$ Sometimes narrations are performed on general gatherings for entertainment too.

Another important characteristic of Wari Leeba is that it still continues the Guru-Shishya Parampara. The students go to their teacher's residence regularly or stayed there for the whole period of their learning this art. There are no established school or institution for this art form and the lessons are imparted by teachers who themselves are narrators to the younger lot especially through personal interactions. The mode of passing over of this art and the story is thorough oral tradition and intense, rigorous practice under their respective tutors. Sometimes the students seek guidance from certain teachers who are well known for their knowledge in particular kanda of Ramayana. Usually the learners go to several teachers for mastering this art which continues even when they become professional narrators also. The reason is that some narrators have specialization in certain stories or episodes like Ojha Kondumba ${ }^{\text {viii }}$ who is specialized in Sundara Kanda of Ramayana. They knew the inner core of narration of specific parts or stories and thus it is important to regularly visit the guru for partaking of the knowledge. Prominent narrators like Wahengbam Ojha, Ngashekpam Tombi received special robes of honour (Khamen Chatpa) from the kings in recognition of their narrative art. But no record for any permanent royal post has been found. Basically in this connection, it is worth mentioning that one of the major factors for the flourishing and sustenance of this art form is the patronage of the Kings who have Vaishnavite faith. Maharaj Garibniwaz and Maharaja Bhagyachandra's names are worth taking as example. Even the last King of Manipur, before the merger of Manipur into Indian Union on $15^{\text {th }}$ October 1949, Maharaja Bodhachandra Singh (1941-1955AD) was well known for his interest in this art form. Of course, the survival of this art form cannot be totally attributed to the royal patronage. As mentioned above the narrators are invited by individuals on certain occasions to perform as in swasthi puja and annual death anniversaries. Moreover, the performers are also invited for month long narration of Ramkatha as during Durga Puja and social organizations as well as members of the communities collectively bear the expenses of the performance, thus giving a sense of collective patronization of this art form. Some artists belonging to the older generations talk in nostalgia about the times when each house of a locality contributed whatever they can in terms of flowers, fruits, labour or money for organizing Wari Leeba performance in full spirit of devotion (Bhakti). Although the targeted audiences has been Vaishnavite converts from the early times, but it is open to all sections of the society, irrespective of faith and class and thus there has been no restriction as to who or whom cannot listen to this narrations. Looking into the lineages and the social 
status of the performers also, they belong to both the Brahmin and non-Brahmin. It is more inclined towards the skill and charm of the performers who can mesmerize the audiences with their art of narration. The use of certain techniques like lifting of bolster, hitting it thereby producing a thumping sound and embracing it at appropriate moments, cause certain effects to the listeners. Very often one can see a lot of elderly ones shedding tears when listening to Hanuman's bhakti (devotion) towards Rama, or at the plight of Sita in Ashok Vaan when intimidated by Ravana. Another observation regarding the significance of Wari Leeba with reference to Ramkatha and the cultural markers of Manipur is that information and notions about the set of beliefs and values associated with the community is communicated to the lot through this medium. Information and reason about certain customs are also found embedded in the course of narrating the stories at appropriate time. Especially, the values and customs associated with Hinduism, particularly of Vaishnavism are communicated to the people with ample explanations and rules.

\section{Text and Orality: An ongoing dialogue}

As mentioned before, the Manipuri version of Ramayana is an adaptation of Krittivas's Ramayana in Bengali translated during the time of King Garibniwaz. The text was rendered into Manipuri in Bengali script. But the circulation of texts was limited to a privileged few only as writing and texts were costly affair. With the need for propagation of Ramanadi faith to the masses, the popularity of narration, exposition and debate became important. Disseminating the core story of Rama, Sita, Lakshman and Hanuman to the newly converted along with a set of rituals that will lead to a heightened sense of devotion and dedication became the need of the hour. Thus oral transmission along the lines of Wari Leeba, Lairik Thiba Haiba, Lairik Taba was popularized. Pertaining to the main focus of this paper, my observation is there has been an ongoing dialogue between the written Ramayana of Manipur and the oral recitation of the Ramayana by the Wari Leeba performers. Starting from the compilation of the Manipur Ramayana, one can guess certain elements of association with oral components. Kshema Singh Moiramba, at the instruction of the King Garibniwaz who felt that the story of Rama should be translated into the local language so as to unable his subjects to hear the Ramayana, rendered Krittivas's Ramayana into Manipuri along with a select group of associates. A court minstrel Pramananda Nongyai Khumanthemba was also among composers of this text. It is highly probable that the composition was tuned to the sung pattern followed at that time. In the words of Ch. Manihar, the work (Manipuri Ramayana) is, without doubt, meant to be sung or recited. He further added that the comparative simplicity in language, unrestrained flow of the narrative and presentation of it in a local atmosphere are the tour-de-force of the writer $(s)$. The construction of the storyline is also such that it gives scope for the narrators to infuse, divert, lengthen or foreshortened the story which could be understood through the discourse on oral narration and the fluidity of the narrative act. In the context of Manipuri Ramayana and its oral rendering, one can notice the way how the story of the arrival of Hanuman at Lanka after crossing the ocean is expressed in Sundara Kanda episode. In the textual version, the story simply mentions the arrival of Lanka on the shores of Lanka in the evening. But in the oral rendering it was made into such a dramatic and vivid experience. The oral narration goes like:

"...The moment Rama Bhakta, Hanuman landed on the shore of Lanka, the entire Lanka felt a great tremor (Bhumi Kampa). Such the intensity of the tremor was that several buildings of Lanka collapsed and the king, Ravan also fell rolling down from his majestic thrown onto the ground. But he recovered himself and try to stay calm and composed in the likeliness of a great king. Sensing that it is an omen, he ordered his astrologers in an angry voice to find the cause for the sudden tremor as well as its remedy. All the famous astrologers of Lanka hurried to the palace and begin to consult their almanac and among themselves. But they couldn't give any satisfying answer for the cause of the earthquake. Then they advised Ravana to consult Vibhisana, his younger brother who also happens to be a great astrologer....'ix And the story goes on. What I have outlined here is a very simple structure of the narration. But while the listening to the narration in one of the Wari leeba performances, it was quite a mesmerizing experience. 
The way the narrator narrates the shaking of the entire Lanka, the toppling of Ravana from the throne and the awkward moment of Ravana when he lays flat on the ground in front of his entire courtiers are fascinating and melodramatic in nature. This caters to the Humor or Hasya Rasa related to the audience. Then, the subsequent story involving Vibhishan turns towards a rather soft and devotional mode. Vibhisana sensing that a Bhakta of Rama has come to Lanka and that he will be blessed to have a glimpse of the Bhakta is beautifully narrated. Thus one sees that the seemingly rigid textual version is transcended into a more flexible and presentable mode of narration which caters to the taste, need and desire of the listeners. It becomes more of a direct interaction between the text and the audience through the medium of the Wari Leeba narrators. Thus from the above instances, it can be inferred that Wari Leeba operates in such a way that the process of dialogue between orality and textual traditions existed side by side in the Manipur literary and social milieu. This is facilitated by the characteristic attributes of the community who produced as well as consumed these forms in the consumption aspect of the traditions also opened up rather fruitful dimensions for studying the involvement of the community in their act for controlling and dissemination of the literary traditions within the sectarian group as well as the process of negotiation and acculturation with other literary and cultural elements. Interaction between the scripto centric tradition of literary production, the phono and the body centric traditions provide a platform for negotiation and interaction between the various forms of expressions and other variants, it be religion or faith or set of cultural elements. It is quite imperative that the narrative art of Wari Leeba contests the neatly generalized definitions of scripto-centric, phono-centric dichotomies proposed for documentation of knowledge within the modernistic framework which connects literature with literacy, writing systems, creativity, intellectually, and are individualistic in nature. Thus, Wari Leeba, Lairik could be understood from this angle where the constituent elements of Vaishnaism and the indigenous Meitei traditions are negotiated at various levels ranging from religious, practices and even forms of literary expressions.

Author acknowledges the valuable information provided by Shri Ahanthem Chaoba Singh, Shri Aribam Chitrashwar, Shri Takhellambam Shyamkanhai and Ojha Kondumba in writing this paper.

\footnotetext{
${ }^{\mathrm{i}}$ Kriti Singh, M.1998.Recent Researches in Oriental and Indological Studies (Including Meiteilogy). Delhi: Parimal

ii Manihar, History of Manipuri Literature

${ }^{\text {iii }}$ Roy, Jyotirmoy. 1958. History of Manipur.

${ }^{\text {iv }}$ An example is the recent debate regarding the name of the seat which the narrator sits while performing, whether it is called Vyaas's ashran or not.

${ }^{v}$ Nilakanta Singh, E. 1993. Fragments of Manipuri Culture. Delhi: Omsons Publications.

${ }^{\mathrm{vi}}$ Ibid. pp.78

${ }^{\text {vii }}$ The author has come across this belief in certain articles on Manipuri Ramayana by several scholars. In an interview conducted by the author, Aribam Chitrashwar a senior renowned scholar in March 2016, also admitted that till recent times it was common for couples to perform recitation session for seeking boon.

${ }^{\text {viii }}$ It is a common practice till date to go to a senior guru for Lairik Oraiba i.e. to read out loudly. T.Sahyamkanhai, a young budding narrator frequents Ojha Kondumba for knowledge on Sundara Kanda of Ramayana.
} 
ix This is transcribed from the author's audio-video recording of a performance by Shyamkanhai in September 2016 at Uripok, Imphal during Durga Puja festival

\section{References}

1. Devi, Jamini. 2010. Cultural History of Manipur. New Delhi: Mittal Publications.

2. Kaushal, Molly, Alok Bhalla, Ramakar Pant. Eds. 2015 Ramkatha in Narrative, Performance and Pictorial Traditions. New Delhi: Aryan Books International

3. Satyanath, T.S. 2006. "Processes and Models of Translation: Cases from Medieval Kannada Literature". Translation Today.

4. Singh, E. Nilakanta. 1993. Fragments of Manipuri Culture. New Delhi: Omsons Publications.

5. Singh, M. Kriti. 1980. Religious Developments in Manipur in the $18^{\text {th }}$ and $19^{\text {th }}$ Centuries. Imphal: Manipur State Kala Akademi. 1980 and

6. Singh, Manihar Ch. 2003. A History of Manipuri Literature. New Delhi: Sahitya Akademi.

7. Singh, Ningthoukhongjam Khelchandra.1969. Ariba Manipuri Itihas ( History of Old Manipuri Literature). Imphal.

8. Singh, R.K. Jhalajit. 1976. A History of Manipuri Literature, Vol.1. Imphal: Manipur University. 